\title{
PERBEDAAN ANTARA KEMANDIRIAN BELAJAR DENGAN GAYA BELAJAR SISWA KELAS VII DI SMP NEGERI 14 KOTA BENGKULU
}

\author{
Esti Fitriya, Hadiwinarto, Arsyadani Mishbahuddin \\ Prodi Bimbingan dan Konseling Fakultas Keguruan dan Ilmu Pendidikan \\ Universitas Bengkulu \\ Estyfitria21@gmail.com, hadiwin@unib.ac.id, arsyadani@unib.ac.id
}

\begin{abstract}
ABSTRAK
Penelitian ini bertujuan untuk menggambarkan bagaimana kemandirian belajar dan gaya belajar yang diadopsi oleh siswa kelas VII SMP Negeri 14 Kota Bengkulu. Sampel peneitian berjumlah 50 orang siswa yang diambil dengan teknik simple random sampling dari kelas VIII. Penelitian ini adalah penelitian deskriptif kuantitatif. Instrumen yang digunakan dalam penelitian ini adalah kuesioner kemandirian belajar dan kuesioner gaya belajar. Data dianalisis dengan menggunakan bantuan software Statistical Package for Social Science (SPSS) versi 16, dengan Crosstabs. Hasil peneitian menunjukkan bahwa, tingkat kemandirian belajar siswa kelas VII SMP Negeri 14 Kota Bengkulu dibedakan menjadi tiga jenis, yaitu tinggi dengan skor 34,0\%, sedang dengan skor $62,0 \%$ dan rendah dengan skor $4,0 \%$. Sedangkan gaya belajar yang diadopsi oleh mayoritas siswa kelas VII SMP Negeri 14 Kota Bengkulu ialah gaya belajar visual dengan skor $60,0 \%$ dan $40,0 \%$ yang mengadopsi gaya belajar auditorial.
\end{abstract}

Kata kunci : kemandirian belajar, gaya belajar

\section{DIFFERENCE BETWEEN LEARNING INDEPENDENCE WITH LEARNING STYLE STUDENT THE CLASS VII SMP NEGERI 14 BENGKULU CITY}

\begin{abstract}
This study aims to describe how learning independence and learning styles are adopted by class VII students of SMP Negeri 14 Kota Bengkulu. The research sample was 50 students taken by simple random sampling technique from class VIII. This research is quantitative descriptive research. The instruments used in this study were learning independence questionnaires and learning style questionnaires. Data were analyzed using Statistical Package for Social Science (SPSS) software version 16, with Crosstabs. The results of the study show that the level of learning independence of class VII students of SMP Negeri 14 Kota Bengkulu is divided into three types, namely high with a score of $34.0 \%$, moderate with a score of $62.0 \%$ and low with a score of $4.0 \%$. While the learning style adopted by the majority of the seventh grade students of SMP Negeri 14 Kota Bengkulu was a visual learning style with a score of $60.0 \%$ and $40.0 \%$ who adopted an auditory learning style.
\end{abstract}

Keywords:learning independence, learning style

\section{Pendahuluan}


Belajar adalah aktifitas di sekolah merupakan inti dari proses pendidikan di sekolah. Belajar merupakan alat utama bagi peserta didik dalam mencapai tujuan pembelajaran sebagai unsur proses pendidikan di sekolah.

Pendidikan adalah pembelajaran pengetahuan, keterampilan, dan kebiasaan sekelompok orang yang diturunkan dari satu generasi ke generasi berikutnya melalui pengajaran, pelatihan, atau penelitian (Lathifa, 2015: 4).

Tujuan pembelajaran dalam suatu kegiatan pembelajaran hanya dapat dicapai jika ada interaksi belajar mengajar antara guru dan peserta didik dalam proes pembelajaran di kelas. Interaksi tersebut harus dalam proses komunikasi yang aktif dan edukatif antara guru dan peserta didik saling menguntungkan kedua belah pihak agar proses pembelajaran dapat berjalan secara efisien dan efektif. Hanya dengan proses pembelajaran yang baik, tujuan pembelajaran dapat dicapai sehingga siswa mengalami perubahan perilaku melalui kegiatan belajar (Hadis, 2006: 59).

Menurut Langeveld (dalam Tirtarahardja, 2010: 37), kekurang pahaman pendidik terhadap pendidikan dapat mengakibatkan kesalahan di dalam melaksanakan pendidikan, namun banyak usaha yang dilakukan dalam perbaikan proses pembelajaran di sekolah yang dapat dilakukan, diantaranya adalah dengan memahami gaya belajar dan kemandirian belajar siswa untuk meningkatkan rasa percaya diri, berfikir kreatif, dan rasa ingin tahu siswa. Gaya belajar sendiri terdiri dari 3 macam jenis yaitu gaya belajar visual atau gaya belajar yang lebih mengutamakan ketajaman penglihatan, gaya belajar auditorial atau gaya belajar yang lebih mengandalkan pendengaran, serta gaya belajar kinestetik atau gaya belajar yang lebih banyak menggunakan gerak fisik.

Gaya belajar sangat penting dan sangat menentukan bagi siapapun dalam melaksanakan tugas belajarnya, siapapun dapat belajar dengan lebih mudah, ketika ia menemukan gaya belajar yang cocok dengan dirinya (Marpaung \& Napitupulu, 2014: 25). Menurut DePorter \& Hernacki (2015: 37) gaya belajar seseorang adalah kombinasi dari bagaimana ia menyerap, dan kemudian mengatur serta mengolah informasi.

Kemandirian belajar merupakan faktor yang mempengaruhi hasil belajar siswa. Siswa yang memiliki kemandirian belajar yang tinggi akan berusaha menyelesaikan tugas yang diberikan oleh guru, sebaliknya siswa yang memiliki kemandirian belajar yang rendah akan tergantung pada orang lain (Fitriana dkk, 2015: 86). Kemandirian belajar merupakan 
kesiapan dari individu yang mau dan mampu untuk belajar dengan inisiatif sendiri, dengan atau tanpa bantuan pihak lain dalam hal penentuan tujuan belajar, metode belajar, dan evaluasi hasil belajar (Tahar \& Enceng, 2006: 91).

Hasil observasi di SMP N 14 Kota Bengkulu khususnya siswa kelas VIII, peneliti memperoleh banyak gambaran permasalahan yang dialami siswa, sebagian siswa memiliki kemandirian belajar yang beragam sehingga hal ini penting untuk diteliti. Ada sebagian siswa cenderung bergantung kepada teman dalam proses belajar dan ada siswa yang tidak pernah mengikuti proses belajar mengajar dengan serius sebelum diinstruksi oleh guru. Selanjutnya peneliti melihat banyak siswa yang belum begitu memahami gaya belajar yang tepat pada dirnya sendiri, sepert tidak membuat catatan saat guru mengajar, berjalan kesana kemari dan beristirahat sebentar saat mengerjakan latihan soal, serta sulit berkonsentrasi. Peneliti melihat guru yang menegur beberapa orang siswa dalam proses belajar mengajar, dan ada siswa yang mengabaikan teguran guru saat proses belajar sedang berlangsung.

Hasil wawancara dengan guru bimbingan dan konseling menunjukkan, salah satunya yang sering guru BK temukan saat ini yaitu siswa mengalami masalah dalam belajar dimana banyak sekali ditemui siswa yang tidak memiliki kemandirian dalam belajar seperti siswa sering mencontek, tidak bertanngung jawab, cenderung bergantung pada teman dikelas yang memiliki prestasi, tidak memiliki rasa percaya diri dalam belajar, bahkan ada siswa yang tidak dapat memahami apa yang sudah guru jelaskan saat proses belajar sedang berlangsung.

\section{Metode Penelitian}

Metode yang digunakan dalam penelitian ini adalah metode deskriptif kuantitatif karena data hasil penelitian berupa angka-angka, dan analisis data menggunakan statistik untuk menganalisis variabel kemandirian belajar dengan gaya belajar siswa. Menurut Nazir (1998: 105) tujuan dari penelitian deskriptif adalah untuk membuat deskripsi gambaran atau lukisan secara sistematis, faktual dan akurat mengenai fakta-fakta, sifat-sifat, serta hubungan antar fenomena yang diselidiki.

\section{Gambar 1 Kerangka Pikir}

Variabel Bebas

$(+)$

Gaya Belajar $\mathrm{X} 1$
Variabel Terikat

$(+)$

Kemandirian Belajar

Y2 
Keterangan:

1. Variabel X1 adalah Gaya Belajar

2. Variabel Y adalah Kemandirian Belajar

Gambar 1 ini mendefinisikan bagaimana gaya belajar dan kemandirian belajar dari siswa kelas VII SMP Negeri 14 Kota Bengkulu. Tujuan penelitian ini adalah untuk mendeskripsikan bagaimana gaya belajar siswa dan kemandirian belajar siswa kelas VIII di SMP Negeri 14 Kota Bengkulu.

Populasi dalam penelitian ini adalah seluruh siswa kelas VIII di SMP Negeri 14 Kota Bengkulu yang berjumlah 244 siswa. Sementara sampel dalam penelitian ini adalah 100 siswa yang terbagi menjadi 3 kelas yaitu kelas VIII.6, VIII.7, dan VIII.8. Pengambilan sampel menggunakan teknik Simple Random Sampling yang artinya pengambilan sampel secara acak. Selanjutnya sampel pada penelitian ini terbagi menjadi 2 yaitu sampel uji coba dan sampel penelitian.

a) Sampel Uji coba

Sampel uji coba dalam penelitian ini berjumlah 40 orang yang diambil secara acak dari populasi penelitian, dan mempunyai ciri-ciri yang mirip dengan sampel penelitian.

b) Sampel penelitian

Sampel pada penelitian ini berjumlah 100 orang siswa yang diambil secara rata dari 3 kelas. Dalam hal ini peneliti menggunakan rumus Slovin untuk menentukan ukuran sampelnya.

$\mathrm{n}=\frac{N}{N \cdot d^{2}+1}$

(Riduwan, 2010: 71 )

Keterangan:

$\mathrm{n}=$ Jumlah sampel

$\mathrm{N}=$ Jumlah populasi

$\mathrm{d}^{2}=$ Presisi (ditetapkan 10\% dengan tingkat kepercayaan 90\%)

Berdasarkan rumus tersebut diperoleh jumlah sampel sebagai berikut:

$\mathrm{n}=\frac{N}{N \cdot d^{2}+1} \quad \mathrm{n}=\frac{100}{100 \cdot 0,1^{1}+1}=50$ responden

Suatu instrumen dikatakan valid apabila fungsinya memberikan hasil yang sesuai dengan tujuan penelitian dilakukan. Uji validitas pada penelitian ini menggunakan daya beda darisoftware SPSS versi 16.0for windows. Langkah awal adalah menguji validitas butir 
kuesioner dengan melakukan uji coba kuesioner ke sejumlah responden sampel uji coba yang diduga mempunyai ciri-ciri mirip dengan responden sampel penelitian.

Penelitian ini bersifat kuantitatif validitas datanya menggunakan statistik dengan rumus daya beda dengan Pernyataan kuesioner dinyatakan valid jika >0,3untuk sampel 40 (Syamsudi, 2012).Reliabilitas merujuk pada suatu instrumen yang memberikan hasil dipercaya serta konsisten berapa kalipun digunakan. Pengujian reliabilitas menggunakan software statistical packages for social scince (SPSS) versi 16.0. Instrumen dinyatakan reliabel jikamemiliki Alpha Cronbach >0,8dan dinyatakan tidak memiliki reliabilitas yang baik jika $<0,8$. Dari hasil pengolahan uji reliabilitas diperoleh hasil Cronbach's Alphagaya belajar sebesar 0,935 > 0,8 dan diperoleh hasil Cronbach's Alpha kemandirian belajar sebesar 0,947> 0,8 dengan demikian instrumen yang digunakan memiliki reliabilitas yang baik.

Uji hipotesis ini dilakukan untuk mengetahui hubungan antara kedua variabel, arah hubungan, serta kekuatan hubungan antara kedua variabel yaitu kemandirian belajardan gaya belajar. Uji hipotesis ini dilakukan dengan bantuan software Statistical Package for Social Science (SPSS) versi 16, dengan Crosstabs.

Tabel 1

Gaya Belajar Kemandirian Belajar Crosstabulation

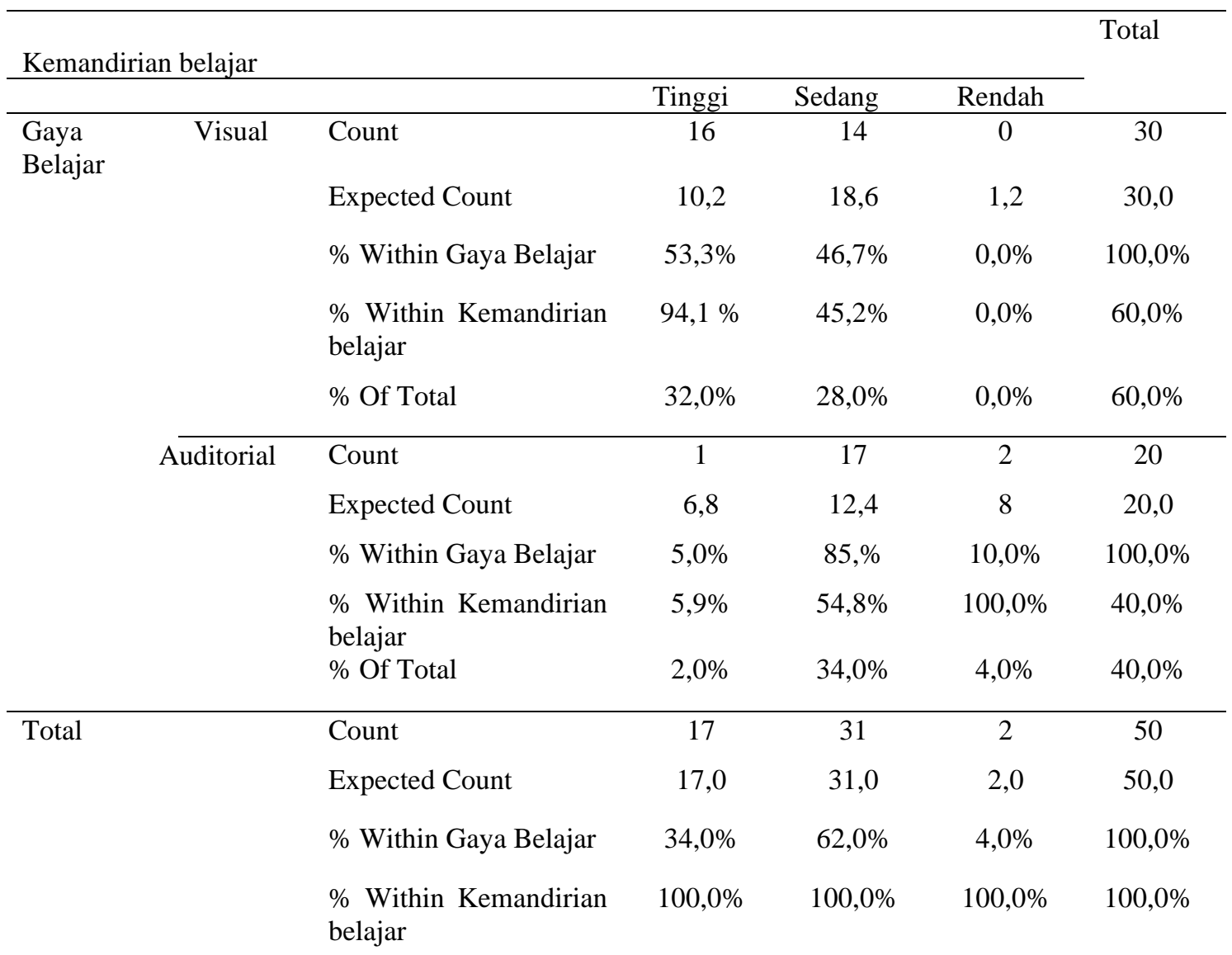


Fitriya, Hadiwinarto, Mishbahuddin

$\begin{array}{lllll}\% \text { Of Total } & 34,0 \% & 62,0 \% & 4,0 \% & 100,0 \%\end{array}$

Berdasarkan hasil perhitungan kemandirian belajar dengan gaya belajar yang ditunjukkan pada tabel 1 di atas, maka dapat dilihat bahwa kemandirian belajar di bedakan menjadi tiga jenis, yaitu tinggi, sedang dan rendah yang dikaji melalui gaya belajar yang terdiri dari gaya belajar visual dan auditorial. Skor pada tingkat kemandirian belajar tinggi ialah 34,0\%, yang terdiri dari 32,0\% gaya belajar visual dan 2,0\% gaya belajar auditorial. Skor pada tingkat kemandirian belajar sedang ialah $62,0 \%$, yang terdiri dari $28,0 \%$ gaya belajar visual dan $34,0 \%$ gaya belajar auditorial. Sedangkan skor pada tingkat kemandirian belajar rendah ialah $4,0 \%$ yang merupakan gaya belajar auditorial sedangkan gaya belajar visual ialah $0,0 \%$.

\section{Hasil dan Pembahasan}

Dalam penelitian ini, yang menjadi tujuannya ialah SMP mendeskripsikan bagaimana kemandirian belajar dan gaya belajar yang diadopsi oleh siswa kelas VII SMP Negeri 14 Kota Bengkulu. Uji hipotesis dalam penelitian ini dilakukan dengan bantuan software Statistical Package for Social Science (SPSS) versi 16, dengan Crosstabs. Sebelum pemberian treatment peneliti terlebih dahulu menentukan skor kategori sebagai berikut:

Tabel 2

Penentuan Kategori

\begin{tabular}{cc}
\hline Kategori & Perhitungan \\
\hline Tinggi & $X<(\mu-1,0 \boldsymbol{\sigma})$ \\
\hline Sedang & $(\mu-1,0 \boldsymbol{\sigma}) \leq X<(\mu+1,0 \boldsymbol{\sigma})$ \\
\hline Rendah & $((\mu+1,0 \boldsymbol{\sigma})$ \\
\hline
\end{tabular}

Menurut Elfiandri (2014: 86) kemandirian belajar siswa adalah kelakuan atau tingkah laku individu siswa dalam menghadapi tanggung jawabnya sebagai siswa dengan kemampuannya sendiri tanpa menggantungkan pada orang lain sesuai batas kemampuannya. Dalam melakukan aktivitas, belajar setiap siswa dituntut kemandirian belajarnya. Dengan adanya sikap tersebut, siswa cenderung memperoleh hasil belajar yang optimal. Berdasarkan hasil penelitian, kemandirian belajar siswa di bedakan menjadi tiga jenis, yaitu tinggi, sedang dan rendah. Kemandirian belajar tinggi memiliki skor 34,0\%, kemandirian belajar sedang dengan skor $62,0 \%$ dan kemandirian belajar rendah dengan skor 4,0\%. Artinya bahwa tingkat kemandirian belajar siswa kelas VII SMP Negeri 14 Kota Bengkulu tergolong sedang dengan skor $62,0 \%$ 
Nasution (2005: 94) mengemukakan gaya belajar adalah cara konsisten yang dilakukan oleh seorang siswa dalam menangkap stimulus atau informasi, cara mengingat, berpikir, memecahkan soal dan menggunakan perangsang-perangsang yang diterimanya dalam proses belajar. Terdapat dua gaya belajar dalam penelitian ini, yaitu gaya belajar visual dan gaya belajar auditorial.

Orang dengan gaya belajar visual cenderung lebih menitikberatkan kepada penggunaan ketajaman pengelihatannya dalam belajar. Orang dengan kategori ini memiliki ciri-ciri mempunyai kebutuhan yang tinggi untuk melihat dan menangkap informasi secara visual sebelum mereka memahaminya. Dapat dikatakan bahwa mereka lebih mudah menangkap pelajaran lewat materi gambar. Mereka juga memiliki kepekaan yang kuat terhadap warna, di samping memahami materi yang cukup terhadap warna mereka sulit mengikuti anjuran secara lisan dan sering salah menginterpretasikan kata (Kurniawan dalam Amir dan Zulfanah, 2008: 121). Sedangkan orang dengan gaya belajar auditorial lebih mengandalkan pendengarannya untuk menerima dan memahami informasi. Untuk dapat mengingat dan memahami suatu informasi, orang tersebut harus mendengarnya terlebih dahulu. Orang dengan gaya belajar ini mengalami kesulitan dalam menyerap langsung informasi dalam bentuk tulisan, juga mengalami kesulitan dalam membaca dan menulis (Kurniawan dalam Amir dan Zulfanah, 2008: 123).

Berdasarkan hasil penelitian terdapat 60,0\% siswa kelas VII di SMP Negeri 14 Kota Bengkulu mengadopsi gaya belajar visual dan 40,0\% yang mengadopsi gaya belajar auditorial. Artinya bahwa mayoritas siswa kelas VII SMP Negeri 14 Kota Bengkulu mengadopsi gaya belajar visual denga skor $60,0 \%$.

Gaya Belajar pada seseorang bersifat individual. Marlene (2004: 14) mengemukakan tidak ada yang dapat mengerjakan keinginan untuk cara belajar dan menganggap semua orang akan belajar serta tidak mudah bagi seseorang untuk menilai antara siapa yang cerdas dan tidak. Setiap orang memiliki kemauan dan gaya belajar yang berbeda-beda. Salah satu faktor yang menunjang dalam keberhasilan belajar siswa adalah gaya belajar. Gaya belajar adalah cara seseorang mempelajari informasi baru. Cara belajar yang dimaksud adalah kombinasi dari bagaimana seseorang menyerap dan mengolah informasi baru tersebut.

Nasution (2005: 91) juga menambahkan bahwa individu dalam belajar memiliki berbagai macam cara belajar. Ada yang belajar dengan cara mendengarkan, ada yang belajar dengan membaca serta ada yang belajar dengan cara menemukan. 
Kemandirian belajar dapat terlihat dari karakter yang terdapat pada siswa. Johson (dalam Waluyo, 2008: 225) menjelaskan ada lima karakter orang mandiri yakni : kompetisi, berani mengambil keputusan, memiliki inisiatif dalam memecahkan masalah, percaya diri, dan bertanggung jawab. Siswa dengan kemandirian belajar akan memiliki kompetisi baik berupa keterampilan mampu belajar ilmu pengetahuan. Siswa memiliki inisiatif untuk memecahkan masalah dengan keberanian dalam mengambil keputusan. Siswa dengan percaya diri menyampaikan pendapatnya karena didukung oleh kompetensi. Siswa memiliki tanggung jawab atas keputusan inisiatif yang diambil. Karakter mandiri dapat tercermin dalam kemandirian belajar.

Siswa yang mandiri tidak lagi membutuhkan perintah dari guru atau orang-tua untuk belajar ketika di sekolah ataupun di rumah. Siswa yang mandiri telah mempunyai nilai yang dianutnya sendiri dan menganggapnya bahwa belajar bukanlah sesuatu yang memberatkan, namun merupakan sesuatu yang telah menjadi kebutuhan bagi siswa untuk meningkatkan prestasi di sekolah.

Menurut Goklap (2013: 89), pembelajaran sebaiknya didesain untuk meningkatkan gaya belajar siswa dan strategi pembelajaran untuk semua tingkat. Jika siswa mengetahui gaya belajar yang mereka miliki maka proses belajar di dalam kelas akan berjalan optimal. Demikian juga dengan guru, sebagai seorang pendidik seharusnya mampu mengetahui gaya belajar siswanya. Dengan mengetahui gaya belajar siswa, guru cenderung mudah dalam mengelola dan melaksanakan pembelajaran di kelas. Guru lebih mudah memilih model, strategi, pendekatan dan metode yang akan digunakan dalam proses pembelajaraan.

Penelitian ini telah dilaksanakan sesuai dengan prosedur ilmiah, namun masih memiliki berbagai keterbatasan, di antaranya adalah keterbatasan penelitian dalam meneliti variabel lain yang berkaitan. Pada penelitian ini kemandirian belajarberkorelasi dengan gaya belajar belum tentu berkorelasi dengan variabel lain. Selain itu, hasil temuan penelitian ini hanya terbatas pada siswa kelas VIII SMP Negeri 14kota Bengkulu. Hasil temuan bisa saja berbeda jika dilakukan di sekolah lain.

\section{Kesimpulan}

Berdasarkan hasil analisis data yang telah dilakukan dapat ditarik kesimpulan bahwa tingkat kemandirian belajar siswa kelas VII SMP Negeri 14 Kota Bengkulu dibedakan menjadi tiga jenis, yaitu tinggi dengan skor $34,0 \%$, sedang dengan skor $62,0 \%$ dan rendah 
dengan skor 4,0\%.Mayoritas siswa kelas VII SMP Negeri 14 Kota Bengkulu mengadopsi gaya belajar visual dengan skor $60,0 \%$ dan $40,0 \%$ yang mengadopsi gaya belajar auditorial.

\section{Daftar Pustaka}

Amir, F. \& Zulfanah. (2008). Menyiapkan Anak Jadi Juara. Jakarta: Komps Gramedia.

Deporter, B. \& Hernacki, M.(2015). Quantum Teaching. Bandung: KAIFA.

Elfindri, H. E., Abidin, Z., \& Machmud, R.(2011). Pendidikan Karakter Kerangka, Metode Dan Aplikasi Untuk Pendidikan Dan Profesional. Jakarta: Baduose Media Jakarta.

Golkap, M. (2013). The Effect of Student's Learning Stlyesto Their Academic Secces. Internasional Elektronic Journal of Mathematics Education. Vol. 4 No. 10, 19-21.

Hadis. (2006).Psikologi Dalam Pendidikan. Bandung: Alfabeta.

Lathifa, W.A. (2015). Hubungan Antara Penalaran Moral Dengan Kecerdasan Spiritual Pada Siswa.Jurnal Pendidikan. Ilmu Pendidikan Universitas Negeri Yogyakarta, Vol. 1 No.3, 3-4.

Nasution. (2005). Berbagai Pendekatan Dalam Proses Belajar \& Mengajar. Jakarta: Bumi Aaksara.

Nazir. (1998). Metode Penelitian. Jakarta: Ghalia Indonesia.

Riduwan. (2010). Skala Pengukuran Variabel-variabel Penelitian. Bandung: Alfabeta.

Tahar, I \& Eceng. (2006). Hubungan antaraKemandirian Belajar dan Hasil Belajar. Jurnal Pendidikan Terbuka dan Jarak Jauh, Vol. 7 No.2, 25-26.

Tirtarahardja. (2005). Pengantar Pendidikan. Jakarta: Rineka Cipta.

Waluyo, S. \& Haryanto.(2008). Ilmu Pengetahuan Sosial Untuk Kelas VII SMP/MTS. Jakarta: Departemen Pendidikan Nasional. 